\title{
D058 THE SYNTHESIS AND REACTIVITY OF PEROXOVANADIUM COMPLEXES AS MODELS FOR VANADIUM HALOPEROXIDASE.
} Gerard I. Colpas and Vincent L. Pecoraro*, Department of Chemistry, University of Michigan, Ann Arbor, MI 481091055.

The recently identified vanadium-containing haloperoxidase found in marine algae[1] is significantly different in function from the better known heme enzymes. Although the precise mechanism for involvment of the vanadium center in the reaction is not well defined[2], a monomeric $V(V)$ is known to be required for activity. The enzyme can utilize iodide, bromide and chloride in halogenations, and in the absence of substrate oxygen is produced by the disproportion of peroxide[3]. The reactions catalyzed are as shown (Eq. 1, 2):

$$
\begin{gathered}
\mathrm{RH}+\mathrm{HX}+\mathrm{H}_{2} \mathrm{O}_{2} \rightarrow \mathrm{RX}+2 \mathrm{H}_{2} \mathrm{O} \\
\mathrm{X}^{-}+\mathrm{H}_{2} \mathrm{O}_{2} \rightarrow 1 / 2 \mathrm{O}_{2}+\mathrm{X}^{-}+\mathrm{H}_{2} \mathrm{O} \\
\mathrm{X}=\mathrm{I}, \mathrm{Br}, \mathrm{Cl}
\end{gathered}
$$

Our goal is to prepare structural and functional models for the vanadium bromoperoxidase using a series of tripodal tertiary amine ligands containing mixed N/O-donor functional groups. These ligands have been used to synthesize various peroxovanadate complexes. The functional groups employed include amine, carboxylate, alkoxy, phenoxy, pyridyl, histidyl, and hydroxylamine. The complexes formed in aqueous solution by the potentially tetradentate donor ligands are characterized by UV/Visible, and NMR $\left({ }^{1} \mathrm{H},{ }^{13} \mathrm{C}\right.$, and $\left.{ }^{51} \mathrm{~V}\right)$ spectroscopies. Complexes isolated in the solid state are analyzed by infrared spectroscopy to give the characteristic metal-peroxo bands, confirmed by $18 \mathrm{O}$ peroxide substitution. The species formed are of two general types, a monoperoxo $\left[\mathrm{VO}\left(\mathrm{O}_{2}\right) \mathrm{L}\right]^{\mathrm{n}-}$ and a diperoxo $\left[\mathrm{VO}\left(\mathrm{O}_{2}\right)_{2} \mathrm{~L}\right]^{\mathrm{n}-}$.

The reactivity and $\mathrm{pH}$ dependence of the complexes are also investigated. The electrochemistry of the peroxovanadium species is determined to provide a measure of oxidation potential in solution. Oxygen production can be observed in both the absence and presence of organic substratc in solutions containing the peroxo complex and iodide. The stability of the peroxide adduct formed and the reactivity obtained with halides and organic substrates is shown to be correlated to the ligand donor type.

1. R. Wever and B. E. Krenn, in Vanadium in Biological Systems: Physiology and Biochemistry, N. D. Chasteen, ed., Kluwer Academic Publishers, Dordrecht, 1990, p. 81.

2. A. Butler and C. J. Carrano, Coord. Chem. Rev., 109, 61 (1991).

3. R. R. Everett and A. Butler, Inorg. Chem., 28, 393 (1989). 